\title{
Darren Aronofsky'nin Mother Filmi ve Baba-nın- Adları
}

\author{
Dr. Öğr. Üyesi Şefik ÖzCAN \\ Mardin Artuklu Üniversitesi \\ GSF, Resim Bölümü \\ mysozcan@gmail.com \\ ORCID: 0000-0001-9913-804X
}

\begin{abstract}
Öz
Bu yazı, Yönetmen Darren Aronofsky'nin Mother (Anne, Darren Aronofsky, 2017) filmindeki teolojik göstergeleri ve filmin bütünselliği içindeki mitolojik anlatıyı, Lacancı Psikanalitiğin kavramlarıyla çözümlemeyi amaçlamaktadır. Başlıkta geçen Baba-nın-Adları ifadesi, Lacan'ın 8 Temmuz 1953 ve 20 Kasım 1963 tarihlerinde on yıl arayla yaptığı ve görünüşte farklı türden konulara dair iki konuşmasına dayanan konferansının devamında, Baba-nın-Adları Semineri'nin adıdır. Makalenin böylesi bir başlıkla ele alınmasının nedenlerinden birini; Yönetmenin, filmin anlatısı içerisindeki yaratma sıkıntısı yaşayan yazarı, Pascal'ın Memorial adlı eserinin başına yazdığı gibi, "(...) filozofların ve bilginlerin Tanrı'sı -olarak- değil, İbrahim'in, İshak'ın, Yakup'un Tanrı'sı(...)" -olarak- tasvir edişi oluşturmaktadır(Pascal Blaise; 1654, s. 02). Diğer nedenlere gelince; Filmin anlatı örgüsünde bir Tanrı'yla gerçekte karşılaşılmışıı. Bir adım ötesinde bir Tanrı'yla birlikte yaşanmıştır. Ve buna rağmen her gerçek gibi, o da erişilmezdir. Ve bu erişilmezlik, aldatmayanla, yani; film boyunca hissettirilen 'kaygı' ile gösterilir.
\end{abstract}

Filmin anlatısı içerisindeki simgeler, 'simge' adına layık bir şekilde işaretlenen cesetlerdir. Bir cesedin etrafında, insan türünü karakterize eden ilişkiler mevcuttur. Tam da bu ilişkiler dolayısıyla cesedin kendisi, yaşamış olduğu gerçeğini, apaçık bir şekilde, orada öylece duran bir 'fazla' olarak muhafaza eder. Bu insanileştiren bir şeye dönüşür.

Filmin tamamı, Lacan'ın 'aktarım' dediği şeyi özetler gibidir. Bu nedenle filmin sonunda, hiçbir Ad'a sahip olmayana yapılan aktarımı vahşet dolu bir törensellik eşliğinde izleriz.

Anahtar Kelimeler: Mother Filmi, Teoloji, Psikanaliz, Lacan

Özcan, Ş. (2019). Darren Aronofsky'nın Mother Filmi ve Baba-nın- Adları. ARTS: Artuklu Sanat ve Beşeri Bilimler Dergisi, 2, ss. 8-21. 


\title{
$\operatorname{arts}=$
}

\section{The Film of Mother By Darren Aronofsky and The Names of The Father}

\begin{abstract}
This study aims to analyze the theological indicators and the mythological narrative in Mother film (Mother, Darren Aronofsky, 2017) within the totality of the film via the notions of Lacanian psychoanalysis. The phrase in the title which is the Names of the Father is the name of Lacan's conference that based on two seemingly different speeches on 8 July 1953 and 20 November 1963. One of the reasons why the article is dealt with such a title is that Aronofsky describes the author, who has a creativity problem in the film, as "(...) not the God of philosophers and scholars, but the God of Abraham, Isaac, and Jacob (...)" as in Pascal's Memorial (Pascal Blaise; 1654, p. 02). If we look at other reasons, a God is encountered in the narrative plot of the film. When we go one step further, the film is lived with a God. And yet, like every truth, it becomes inaccessible. And this inaccessibility is shown by the unfaithful, the "anxiety" felt in the film.

The symbols in the narrative of the film are corpses that are marked as worthy of the concept of "symbol". There are relationships around a corpse that characterize the human species. It is precisely because of these relationships that the body clearly retains the fact that it has lived as a "plus". It turns into something that humanizing.

The whole film seems to sum up what Lacan calls "transference". For this reason, at the end of the film, we watch the transfer to the one who has no name, accompanied by a brutal ritual.
\end{abstract}

Keywords: Mother Film, Theology, Psychoanalysis, Lacan 


\section{arts $=$}

\section{Gíriş}

Darren Aronofsky'nin 2017 yapımı "Mother" (Anne, Darren Aronofsky, 2017) filmi, gerek barındırdığı sinematografik temalar; gerekse film okumaları açısından sahip olduğu zenginlikler bağlamında oldukça tematik bir film olma özelliğine sahiptir. Katıldığı Toronto ve Venedik film festivallerinde eleştirmenleri ikiye bölen film, beraberinde getirdiği estetik okumalar açısından bu bölünmüşlüğün ötesinde anlamlar taşır. Film her şeyden önce oldukça 'Teolojik' bir genel izlek sunar. Başından sonuna kadar, önermelerin çoğunun bu teolojik imlemelerden doğduğunu ve gitgide kaotik bir evren tasarımına doğru evrildiğini izleriz. Filmin başında tekinsiz bir alan olarak 'dış alem', ilksel doğa veya yaradılışın ilk nüvesi olarak dünya imlenirken, korunaklı ve 'güvenli' olarak tanımlanabilecek iç mekan-yani ev (Hitchcock filmlerini hatılatan bir alametifarika!) ikili ve net bir ayrımla ortaya konur. Çevreden nispeten yalıtılmıs olabileceğini hissettiğimiz bir kır evinde yaşayan çifti görürüz öncelikle. Şairyaratıcı rolünde gördüğümüzisimsiz karakter ile (Javier Bardem) ona hayranlıkla bağlı olduğu eşi Veronica-filmde Toprak Ana olarak Gaia- (Jeniffer Lawrence) arasında gerilimli bir ilişki sunumu ile film açılır. Yaratım süreci sıkıntııı yaşayan Şair-Tanrı!-bir başka deyişle 'O' karakteri ilham arayışını, evlerine misafir olarak gelen doktor (Ed Harris) karakteriyle ateşleyecektir. Bu noktada filmin yoğun simgesel anlatımının ilk -ve belki de en belirgin- göstergesi olarak daha önce bahsedilen teolojik vurgu net olarak ortaya konmuş olur. Kitab-IMukaddes'in en temel anlatılarından biri olan Aden bahçesi sabit kamera açısıyla kır evinin hemen karşııında bizlere sunulur. Şair-Tanrı bu noktada deyim yerindeyse Adem'in eve (verili gerçeklikteki yaşanan dünyayı anlamalıyız bu noktada) gelişiyle kendi 'oluş' unu hatıllar. Bu oluş biçimi yaratma güdülenmesiyle kucaklayıcı ve elbette oldukça misafirperver olmak durumundadır. Fakat karşımızdaki oldukça müstehzi bir Adem'dir. Adeta yasak elmayı çoktan yemiş ve hatta bu bilgilenmeyle birlikte oldukça tecrübe sahibi ve özgüvenli bir profil sergiler. Babasına oldukça hayran bir Adem hüviyetindedir dokłor karakteri. O'nun yaratım sürecine ve varoluşuna hayranlık duymaktadır. Bu durum Veronica'yı oldukça rahatsız eder. Ev ya da güven teşkili olarak verili gerçeklik onun için bir tür korunaklı alandır. Doktorun gelişiyse ilk rahatsız edici vurgu olarak bir tür huzursuzluk simgesidir. Her ne kadar teolojik anlatı Adem ve Havva karakterlerini insanlık adına girişilen ortak bir arayışın temsili olarak sunsa da; filmde bu anlatının tersinir sunumlarıyla karşılaşııı. Bu tersinir sunumlar bütünü genel anlatının postmodern 
tezahürü olarak aslında tipik bir Aronofsky plastisitesini aktarsa da teorik düzlemde bu sunumlar bütünü, yazlya konu olan Lacan'cl psikanalizin genel metodolojisine yakındır.

\section{Baba-nın Adları}

Bu düzlemde şair-tanrı ile doktor karakterlerinin karşılaşması, 'Baba'ların' karşılaşmasıdır. 'Bahsedilen simgesel düzenin 'öteki'si ise tedirgin bir kadın olarak Veronica karakteridir. Doktorun öksürük nöbetiyle 'O' tarafından banyoya götürülüşü ve bu esnada Veronica'nın doktorun kaburga yarasını fark edişi ve akabinde O'nun bu yarayı gizleyişi adeta Adem'in kaburgalarından doğan Havva'yı ve bu bilgilenişten memnun olmayan ana erkek karakterin-yani Tanrı'nın- aynı karede işlenmesini gerektirmiştir. Nitekim bu sahneden hemen sonra Havva karakteri de doğmuş olacak ve akabinde ertesi gün evin kapısında doktorun eşi olarak kendisi görüyor olacağız. (Michelle Pfeiffer)

Baba figürlerinin bu ele alınış şekli Lacan'ın Baba-nın-Adları isimli seminer notlarının bir araya getirildiği çalışması ışığında daha da anlamlı hale gelir. Baba figürleri öznenin bir tür 'başka'nın etkisi altında; onun kaygısının nesnesi olarak vücu†

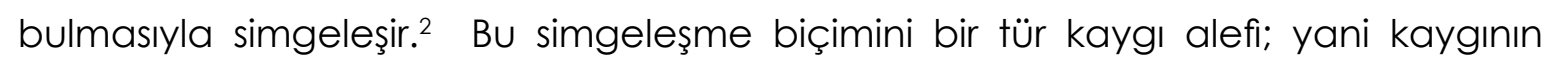
simgeleşmesi olarak Veronica'nın bakışında görmemiz mümkün olur. Doktor ve şair/ yazar (O) karakterleri, böylece bu bakışın etkisi altında özneleşirler. Bu özneleşme biçimi aynı zamanda simgesel düzenin de kurgusunu güçlendiren bir oluştur. Böylesi bir simgesel düzende özne Başka'nın arzusundan etkilenir. Özne tam da kaygılı olduğu anda ötekinin arzusundan etkilenir pozisyondadır. ${ }^{3}$ Lacan'ın ifadesiyle "Özne bu arzudan diyalektikleştirilebilir olmayan doğrudan bir tarzda etkilenmiştir. Işłe bu bakımdan kaygı, öznenin etkilenimleri arasında, aldatmayandır. ${ }^{4}$ Tam da bu sebepten ötürü Veronica'yı bütün duygulanımlarında, olaylara verdiği tepkilerde oldukça dürüst ve doğrudan görürüz. Veronica adeta ötekinin aynasında kendine bakan bir karakterdir. Kendinde eksik olanı, başkasının arzusuyla oluşturan ve bu yeni oluşta her defasında kaygı-kontrol sarmalında debelenen bir pozisyondadır.

1 Kuşkusuz bu noktada tersine çevrilen sadece teolojik sunumun kendisi değildir. Aynı zamanda Freud'çu psikanalitik görüşün de tersinirlendiğini görürüz. Freud'çu düzlemde baba yalnızca tekil olabilir ve Lacan'ın dem vurduğu büyük simgesel düzenin-yani 'Büyük Öteki' nin dışarda kaldığı sadece seksüel bir figürün kendisidir. Fakat Lacan' $\mathrm{Cl}$ babalar aynı zamanda bir düzenin temsiliyetinin de simgesidirler. Bunun dışında Adem de İsrailoğulları sülalesinin ve dolayısıyla insanlığın ilk atası olması itibariyle Lacan'cı simgesel düzende önemli bir 'baba' figürüdür.

2 Jacques Lacan, Baba-nın-Adları, Monokl Yay., İstanbul, s.73-74.

3 A.e., s.62.

4 A.e., s.63. 
Sürekli olarak eve yeni gelen çiftin eylemlerini kontrol altında tutmaya çalışır ve fakat kontrol altında tutmaya çalıştıkça her şey kontrolden çıkar. Akış düzenindeki chaos evrenin oluşumundaki niteliğini devamlı hatırlatır Veronica'ya.

\section{Eksiklik Olarak Arzu}

Filmin alegorik yapısıla ilişkilenen bir başka durum evin yaşayan bir organizma olarak işlenişidir. 'Anne oluş' adeta evin nesnel yapısında vücuł bulmuştur. Veronica'nın evin kanayışını, nefes alış-verişini hissedişi ve bu durumla ilgilenişi bir annenin çocuğuyla olan ilişkisini hatırlatır. Evin tahrip edilen dünyanın bir temsili olarak göründüğünü hatırlayarak, bu yapıyı sonun kadar korumaya yönelik tutumuyla Gaia'nın oldukça anaç bir sunumuyla karşılaşırı. Öyle ki doktor karakterinin eşinin de eve gelişiyle birlikte, 'öteki'nin bakışının izleğinde şairin ve kendisinin ilişki yapısının analiziyle karşılaşacaktır Veronica. Yasak elma simgeselliğini anıştıran bir nesnenin Şair tarafından dikkatle korunması, bu yasak nesneye Adem (Doktor) ve Havva'(Doktorun eşi) nın ilgisi teolojik düzlemdeki dizgeyi hatırlatır niteliktedir. Ertesi gün bu nesnenin çift tarafından kırılması ile birlikte (yasak elmanın yenişi) Pandora'nın kutusu açılmış ve bilgiler, evren düzleminde öğrenilebilir-ve dolayısıyla paylaşılabilir olmuştur. Nitekim bir sonraki sahnede Adem ve Havva cinselliği de keşfetmiş olacaklardır. Veronica'nın kutsal nesnenin kırımasının hemen akabinde çifti alt katta sevişirken görmesi onların evden sürülmesini gerekli kılacaktır! Bütün bu olaylar neticesinde Veronica yeni gelen çiftle rahatsı edici bir karşılaşma içinde bulur kendini. Doktorun eşinin kışkırtıcı imaları, Veronica'nın çocuk sahibi olamayışıyla bu durumun doktorun eşi tarafından sorgulanması Veronica ve şair arasındaki gerilimi arttıır. Daha dikkatli bakıldığındaysa bu gerilimin özünün bir tür kaygı durumu olduğunu anlarız. Bu kaygı türü elbette Lacan'cı teorizasyonda bir tür duygulanım'a tekabül etmektedir. Bu duygulanım türü özne olarak Veronica'nın, doktorun eşinden transfer ettiği haz duygusudur. Fakat bu haz tam da Freudyen bir tanım olan hazzın ötesinde -yine Lacan'cı terminolojiyle ifade etmek gerekirse bir tür jouissance (haz ötesi tatmin-veyahut bir tür dürtü tatmini) hissiyatıdır. ${ }^{5}$ Dokłorun karısının devamlı surette dolayıma soktuğu cinsel mesajlar Veronica'yı eşine karşı kışkırtır ve aralarındaki cinsel temassızlığın sorumlusu olarak eşini suçlar. Tam da bu 5 Jouissance kavramının detaylı işlenişi ve bu kavram etrafında şekillenen tartışmalar bütünü için bknz: Slavoj Zizek, Yamuk Bakmak, Metis Yayınları, İstanbul 
noktadan sonra Veronica ve eşi arasındaki tutkulu sevişme sahnesiyle jouissance' nin nihai döngüsü tamamlanacaktır. Bu sevişme sonrasında Veronica' nın hamile kaldığını öğreniriz ve olayların boyutu değişir. Bu noktada asıl problematik ise, Veronica'nın arzusunun nedeni ile nesnesi arasındaki uyuşmazlıkta asılı kalmasıdır. Zira Veronica kendi arzusunun değil, doktorun karısının arzusunun nesnesi olarak konumlanıp eşiyle birlikte olmuştur.

Başka bir arzu-sevgi diyalektiği Veronica'yla eşi arasındaki ilişkilenme biçiminde karşımıza çıkar. Veronica eşiyle, kendisine karşı olan sevgiyi devamlı sorgular niteliktedir. Dışardan gelen kişilerin varlığı Veronica'ya bu sevginin varlığını tehdit eden dış etmenler olarak görünür. Dışarısı Veronica için büyük bir tehdittir. Fakat asıl tehdit şairin nezdinde Veronica'nın görmek istediği sevme biçimidir. Veronica Şair/Yazar (O) 'dan kendinde olmayanı vermesini ister. ${ }^{6}$ Aşkın o en yüce karşılığını bekler gibidir fakat 'O'-bu noktada yeniden yaratıcı Tanrı figürü olduğunu hatırlamak gerekir belki de-eve aniden dahil olan doktor ve eşinin çocuklarının da gelişiyle 'iyilik' dağıtmaya devam eder. Onlar birer Tanrı misafiridir ve onlara iyi davranılması gerekir. Bu ani baskın Veronica'yı oldukça rahatsız eder. Doktor ve eşi yetmezmiş gibi artık evde bir de çocuklar vardır. Üstelik başka bir kriz de kardeşin kardeşi katlidir. Filmin teolojik görüngüsü bir kez daha kendini hatırlatır: Adem'in oğullarından Kabil Habil'i çıkan bir tartışma sonucunda evde öldürmüştür. Artık insanlığın eline kan bulaşmıştır ve bu andan itibaren evde bir nevi tufan baş gösterecektir. Önce Şair'in hayranları kapının önünde ufak bir grup olarak ondan imza beklerler. Tam da hamileliğin kutlanacağı bir yemek hazırlığında olan Veronica giderek artan ziyaretçi kalabalığı karşısında iyice huzursuz olur. Başlangıçta dışarda bulunan ziyaretçiler Şair'in davetiyle eve girerler. Bu andan sonra evde çıkan ufak çaplı taşkınlıkları kontrol altında tutmaya çalışan Veronica tek tek bütün olaylara yetişemez. Olaylar da iyice çığııından çıkar. Çeşitli çatışmalar, protestolar, polis güçleri ve devlet temsiliyetini simgeleyen çeşitli gruplar evin içinde tam bir kaos yaratırlar. Bu temsiliyet tipik bir dünya panoraması gibidir ve son süreçte, başta bireyci kaygılarla başlayan ufak krizler yerini toplumsallaşan kaygılara bırakır. Özellikle filmin sonuna doğru kurban mitinin işlendiği sahneler de yine bahsedilen teolojik örgünün bir parçasıdır. Kaosun ortasında doğumu gerçekleşen Veronica' nın bebeği önce eşi tarafından alınır. Veronica bebeği vermekte tereddü† eder çünkü içgüdüsel olarak kötü şeyler olacağını hisseder gibidir. Bebek 'O'nun

6 Konuyla ilgili detaylı tartışma için bknz: Ulus Baker, Sanat ve Arzu, Illetişim Yay., İstanbul, s. 94-95-96-97. 


\title{
$\operatorname{arts}=$
}

elinden topluluğun eline geçer ve elden ele, adeta bir kurban gibi sunağa yatırılır. Veronica kalabalığı yararak hızla sunağa ulaşmaya çalışsa da bebek parçalanır ve her bir parçası toplulukça yenir. Böylece artık günümüz Neo-liberal toplum inşasının yapı taşlarını oluşturan nefret dolu, tüketici bir hoyratlık evin içindeki tebaaya transfer edilmiş olur. Siyasi protestolar, insan kıyımları gibi toplumsallaşan olgular ve bunların sonuçlarıyla yüzleşmek zorundadır Veronica.

Bunlarla birlikte yaşanan olayların yeniden yaşanacağı ve yaşanacakların yaşanmışlıklar üzerinden şekilleneceğine dair genel vurgu filmin karakterleri özelinde de kendini gösterir. Filmde Sarah-Jeanne Labrosse, Jennifer Lawrence ve Laurence Lebeouf aslında aynı karakteri oynamaktadırlar. Labrosse, Lawrence karakteri hayat bulmadan önceki ölmüş olan anne rolündedir. Lebeouf ise, Lawrence öldükten sonra hayata gelecek olan anneyi temsil eder. Böylece filmde gördügümüz yaşanmışlıkların hepsinin başka bireyler nezdinde fakat aynı şekilde yaşanacağı bir döngü işaret edilir. Bu aynı zamanda Nietzsche'ci zaman döngüsünü de hatırlatır bize: Ebedi dönüş mitosu reel gerçeklik olarak karşımıza çıkacaktır. Filme ilişkin bu genel anlatıdan sonra, yer yer tekrara düşmek pahasına da olsa, Lacancı psikanalizin kavramlarıyla çözümlememizi, çapraz okumamızı üçüncü bölümde de devam ettireceğiz.

\section{Psikanaliz ve 'Mother' Filmi}

Paul Eisenstein, 'Sanrılar ve Sayılar: Aronofsky'nin "Pi" Filmi ve İlksel İmleyen' adlı makalesinde, Lacancı psikanaliz çerçevesinde şunları yazar:

\begin{abstract}
Anlam evreni ile çevrili kural dışılığı-var olan Ötekiye ait ( Anne, Doğa, Tanrı) nihai ölümcül zevkin metaforik ifadesini- kabul etmediğimiz zaman, ayakları yere basan özneler olma yolunda edindiğimiz ve sadece ilksel imleyenin, Ötekinin her şeyi yutan o ölümcül zevkini adlandırıp etkisini yok ederek güvenli hale getirdiği o kritik zemini kaybetme riskine girmiş oluruz. Bu "temel metafor"un - Babanın Adı, Doğal Yasakontrolü ele almakta başarısız olması, ötekide kabul edilen bir eksikliğin olmadığı ve Ötekinin niyetlerini, Adın geçersiz yasası ya da söylemleri yoluyla değil libidinal olarak yüklenmiş cennetten kovulmadan önceki döneme ait ilksel imleyenler şeklinde, doğrudan özneye yönelttiği psikozlu bir yapıyı harekete geçirmekle sonuçlanır.(Poul Eisenstein, Lacan ve Çağdaş Sinema, 2014, s. 37)
\end{abstract}

Eisenstein'ın Aronofsky'nin "Pi" (1998) adlı filmini çözümlerken, -Lacan'ın öğrettikleri çerçevesinde- formüle ettiği yukarı da pasaj, Aronofsky'nin "Mother" filminin çözümlenmesi için de kullanılabilir. 
En başından şu söylenebilir; Aronofsky'nin Anne filmi, Lacancı gerçek ve bunun etkileriyle apaçık bir bağlantı içerisindedir. Film, başından sonuna kadar, Büyük Öteki'yi, travmayı, fanteziyi, arzuyu ve zevki, en çok bilinen dinsel-mitsel anlatı olan 'Yaratıış'ın göstergeleri aracıı̆̆ıyla çarpıcı bir şekilde ortaya koyar. Lacancı analiz tam da bu noktada, filmin radikal sayılabilecek yönlerini kilit altından kurtararak, genel izleyicinin deneysel analizinin sağlayamayacağı desteği sağlar.

Anne filminde de, Aronofsky'nin genel sinematografik izleğini takip edebileceğimiz göstergeler mevcuttur. Gerçek, filmin ilerleyen her aşamasında sürekli artarak ortaya çıkar ve bu durum sembol düzenlerinin çöküşüyle birlikte işlenir. Tam da bu durum -gerçeğin ortaya çıkışı ve sembol düzenlerinin çöküşü-, sürekli bir 'kaygı' halindeki Veronica'ya işaret eder. Filmin ana kadın karakteri Veronica, bu anlamda, yaratıcı şair/yazar olarak gösterilen 'O' 'nun, ana imleyen olarak yokluğuyla sürekli yüzleşmek zorundadır ve bu durum onu ruhsal çöküntülere gark eder. Ancak Veronica, bunun altından kalkamaz ve ölür. Onun ölümü, bir tekrarın yeniden sahnelenmesi olacaktır (Bknz: Ebedi Dönüş Mitosu).

Filmin açılış sahnesinde Musa'nın Tanrısı'nı düşünmemize sebep olabilecek yanan çalı metaforunu anıştıran alevler içinde bir kadın imgesi görürüz. Bu imge aynı zamanda sembol düzenlerinde beliren gerçeğin anıdır. Bu an bitişin, son bulmanın ve yeniden başlamanın metaforu gibidir. Bu kısacık açılış sahnesi kadının gözlerinden akan bir damla yaşla son bulur. Bu sahnenin aslında filmin sonunda açığa çıkacak olan sonsuz döngüyü imlediğini fark edeceğiz. Hemen sonrasında gelen sahnede 'O'yu görürüz. Elindeki ışl|tılı, parlak mücevherimsi bir nesneyi sevgiyle elinde tutuyordur ve nesneyi özenle odasındaki ait olduğu yere koyar. Buraya kadar filme ilişkin ilk izlenimimiz filmin bir anlam evrenini içerdiği ile ilgili olacaktır. Üçüncü sahnede Veronica, güzel aydınlık bir sabaha uyanır. Yatağı yoklarken 'O' yoktur. Erken uyanmıştır. Kalkıp evin içinde 'O'nu arar. Sonrasında dış kapıya doğru seğirtir. Dingin, huzurlu bir sessizlikle dolu doğaya açılan dış kapıyı açar. Manzaradan belli belirsiz bir tekinsizlik duyduğunu hissederiz. Bu esnada ' $O$ ' aniden arkasında belirir. Veronica korkar. "Dışarda mıydın? Beni neden uyandırmadın" diye sorar. O: "Yalnız kalmak istedim. Kafamı boşaltmak ve aklıma fikirler gelsin diye" cevap verir. Veronica: "Geldi mi?" diye sorar. O "Hayır" der. Veronica: "Gelecek. Merak etme fikirler gelecek" der. Bu ifade tam da sonrasında olacakların kehaneti gibidir. 


\section{arts}

Veronica, bu kahince sözleriyle, mevcut anlam evrenini çevreleyen kural dışlığın, 'O'nun her şeyi yutan ölümcül zevkini adlandırıp, etkisini yok etmeye çalışarak güvenli hale getirdiği o kritik zemini kaybetme riskine girmiş olur ( Veronica'yı film boyunca 'O' ya ait eski evi, sürekli tamir ederek, yenilemeye çalışırken görürüz. Çünkü 'O'nun ölümcül zevki yaratmaktır ve O sürekli başıboş dolanıp esin beklerken, Veronica evi- güvenli zemini- 'O' için, 'O'nun yaratım süreçleri için, daha iyi bir yer haline getirmeye çalışmaktadır. Bu temel metaforlarda, Hem 'Baba-nın Adı' olarak 'O' da, hem de 'Doğal Yasa' olarak Veronica'da, sonrasında gelişen olaylarda kontrolü ele almaktaki başarısızlıkları, her iki ötekide de aslında bir eksikliğin olmadığı ve ötekilerden birinin; 'O'nun niyetlerini, adın geçersiz yasası ve söylemleri yoluyla değil de, cennetten kovulmadan önceki ilksel imleyenler şeklinde, doğrudan özneye yöneltilen psikozlu bir yapının hareke geçirilmesiyle sonuçlanmasını görürüz.

Lacan, Baba-nın Adları'ında, kaygıyı tanımlarken; "kaygı öznenin bir etkilenimidir / duygulanımıdır" der (Lacan, 2014, s. 34) Lacan'a göre kaygı; bir imleyenin etkisinde temellendirilen ve belirlenen öznenin yapısına oturtulmuş işlevlerden birisidir. Aronofsky'nin filmi, ilk bakışta, bir yaşam inşa etmeye çalışan bir çifti gösterir gibidir. Bütün zamanını yazarlık kariyeriyle geçiren, ancak yaratma sancıları çeken bir adam ve adama yaratma serüveninde destek olmaya çalışıp, sürekli evi yenileyip düzenlemekle uğraşan, aynı zamanda bir çocuk doğurma özlemi içinde olan bir kadın imgesi gözümüze çarpar. Ancak daha filmin ilk birkaç dakikası içinde, kadının (Veronica) bir imleyenin etkisinde belirlenen bir özne olduğunu, yani kaygılı bir özne olduğunu hissetmeye başlarız. Lacan, kaygının nesnesiz olmadığını, kaygının bir nesne nedeni olduğunu belirtir. "Nesne a, kaygılı olduğunda özneden düşendir / eksilendir. Arzunun nedeni diye tarif ettiğimle aynı nesnedir" (Lacan, 2014, s. 63).

'O' ile kadın arasındaki sürekli ertelen cinsel ilişki, başka'nın arzusunun kışkırtıcılığında gerçekleşir. Veronica'nın kaygısı yeni bir düzlemde bir nesne nedene sahiptir artık. Kendisinden düşen/eksilen ve hiçbir Ad'a sahip olmayan bir öteki, sahneye yok olmak / yok edilmek için gelir. "Kaygı ile arzu arasındaki ilişkinin yapısı, özne ile özneden düşmüş/eksilmiş nesne arasında çifte bir yarık kapsar, burada özne, kaygının ötesinde, (...) bu yitik nesnenin başlangıç işlevini bulmalıdır" (Lacan, 2014, s. 67). Veronica' nın hamileliği, çocuğun doğumu ve öldürülüşü, bizi object petit a' yı ve filmin başlarında gördüğümüz mücevherimsi nesneyi yeniden düşünmeye iter. Daha 


\title{
$\operatorname{arts}=$
}

en baştan ilk gerçekleşen olayın zaten özneden düşen/eksilen bir nesne olduğu, -bir sembol düzeni üzerinde beliren travmatik gerçek olarak- gösterilir. Evin davetsiz misafirleri olan doktor ve eşi, mücevherimsi nesneyi ellerinden düşürüp kırarlar. Bir yasağı delmişlerdir. Olayların çığıından çıkmaya başlaması bundan sonradır. Bu açıdan bakıldığında; "Kaygıda nesne küçük a düşer / eksilir. Bu düşüş başlangıçta meydana gelir. Düşen bu nesnenin aldığı biçimlerin çeşitliliği, öznenin Başka'nın arzusunu nasıl anladığıyla belli bir ilişki içindedir. (Lacan, J. s. 71 2014). Sonrasında Doktorla karısı arasındaki, 'O'nun ve Veronica'nın da tanık olduğu sevişme sahnesi gelir. "Oral nesnenin işlevini açıklayan işte budur" (Lacan, 2014, s. 71). Bu işlev, özneden düşen/eksilen nesne, tam da bu anda Başka'nın talebine, anne yapılan çağrıya dahil olur. Annenin arzusu böylece bir ötenin belirteci olur. Oral nesnenin işlevi de bu dolayımda anlaşılabilir.

'O'nun, etrafında gelişen olaylara yönelik tepkilerinde ise, bir ana imleyen demeyelim de, bir özne olarak gelişen şeyleri değerlendirirsek; $O$, evinde olup biten, gerçekleşen her türlü olayı, taşkınlığı memnuniyetle karşılar. Evini, ocağını tarumar eden herkese bir şefkat ve sevgi duyar. Çocuğunun ve karısın ölümüne yol açan güruha karşı bile sevecen ve şefkat doludur. Güruhun kendisine yönelik taşkın sevgi gösterilerine kendisini kaptırmış, yaratıcı gücüne olan övgüleriyle başı dönmüş vaziyettedir. Bu aynı zamanda Lacan'ın özneye yönelik çözümlemelerinin başka bir boyutunu oluşturur. Lacan'ın şu ifadeleri, tam da 'O'nun içinde bulunduğu durumu özetler gibidir:

\begin{abstract}
Skopik itkide, özne dünyayla ona sahip olan bir gösteri olarak karşılaşır. Orada bir tuzağın kurbanıdır, bu tuzak sayesinde özneden çıkan ve onunla yüz yüze gelen şey, hakiki a değil, onun tamamlayıcısı olan yansııııı (speculaire) imgedir. Işte ondan düşmüş / eksilmiş gibi görünen şey budur. Özne kendini gösteriye kaptırmışıı, ona sevinir, ondan haz alır. Aziz Augustinus da bunu, son derece yüce biçimde gözlerin şehveti olarak if̧̧a ve tarif eder. Özne arzu ettiğine inanır çünkü kendini arzulanan olarak görür ve Başka'nın ondan koparıp almak istediği şeyin onun bakışı olduğunu görmez. ( Lacan, 2014, s. 74)
\end{abstract}

Eski Ahit'te Tanrı ile Musa arasında şu diyalog geçer: "Ve Musa Allah'a dedi: İşte, ben İsrail oğullarına geldiğim zaman, onlara: Atalarınızın Allah'ı beni size gönderdi, dersem, ve onlar bana: Onun ismi nedir? derlerse, onlara ne diyeyim? $\mathrm{Ve}$ Allah Musa'ya dedi: Ben, BEN OLANIM; ve dedi: İsrail oğullarına böyle diyeceksin: Beni size BEN IM gönderdi" (ÇIKIŞ, BAP 3, 13-14). Mistisizm, özü itibariyle hemen hemen çoğu kültürde ve geleneklerde, bir arayış, sanı, çile vs. olarak Tanrı'nın 


\section{$\operatorname{arts}=$}

zevkine bir dalıştır. Ancak, Yahudi mistik geleneğinde, Hristiyanca sevgide ve en çok da nevrozda izleri bulunabilecek olan şey, Tanrı'nın arzusunun yankısıdır. Anne filminde gördüğümüz şey de, arzunun burada merkezi bir öneminin olduğudur ve bu arzu, Musa'nın Tanrı'sı olan bir Tanrı'nın arzusudur. Lacana' a göre; "Bu Tanrı' nın adı, yalnızca Ad'dır ve 'Ben Benim' ifadesinde, bu 'Benim'e, 'Benimi'in Ad'ı olmaktan başka verilecek hiçbir anlam yoktur". (Lacan, 2014, s. 84)

Aronofsky, filminde, Javier Bardem'in canlandırdığı karaktere bir isim vermemiştir. Bu karakterden ' $O$ ' diye söz edilir. Film, başından sonuna kadar, 'O'nun istekleri ve kararlarıyla şekillenir. Ve izleyici olarak bizlerde, 'O'nun arzusuna tanıklık ederiz. 'O' yalnızca 'O'dur. Bir ismi yoktur. Burada tam da Derrida'nın isim üzerine yazdığı denemeleri olan 'Çile', 'İsim Hariç' ve 'Khõra' adlı kitaplarında yazdıkları anımalıdır. Derrida her üç kitabında giriş kısmında, 'iliştirilmesi rica olunur' notuyla şöyle yazar:

İsim: bununla neyi çağıııı? (...) Ve bir isim verildiği zaman ne oluyor? Bu durumda ne veriliyor? Bir şey sunulmamakta, bir şey verilmemektedir, ancak bununla birlikte (...), sahip olunmayan bir şeyi verme anlamına gelen bir şey meydana gelmektedir. Özellikle tam da ismin eksik olacağı yerde yeniden-adlandırmak gerektiği zaman ne oluyor? Özel isimden bir tür lakap, aynı anda hem tekil hem de tekil bir biçimde tercüme edilemez bir takma isim veya şifrelenmiş isim yaratan şey nedir" (Derrida, 2008 , s. 5-6).

Musa'nın Tanrısı'nın 'Ben Benim'i; hem özsel hem de yabancı olan mutlak bir gizi söyler. Bu da hesaplanamaz bir borcun ortaya çıktığı bir deneyimi sahneye koymayı gerektirir (Derrida, 2008). Bu borç kime ödenecektir? Borcu ödeyen kim olacaktır? Aronofsky' nin filminin anlatı örgüsü içerisinde, hem özsel hem de yabancı olan mutlak bir gizi, hesaplanamaz bir borcun ortaya çıktığı deneyimin sahnelendiği 'mekan' gayet dikkat çekicidir. Hatta bu mekanın yankısına ilişkin bir ifade mümkün olacaksa, Bu da Derrida'nın isim üzerine denemelerini oluşturan kitaplardan biri olan Khõra' dan çekip alınabilir. Platon'un Timaios' unda; varlık' ın zaman ve uzamda yer alabilmesinin, bir konumu gerektirdiği belirtilir. Bu konuma yatak, kalıp, rahim (doğulan yer) anlamında, Khõra ismi verilir. Khõra, anlaşıldığı kadarıyla Timaios'ta hiçbir şey vermeden sadece 'mahal' verir gibi görünmektedir. Aronofsky' nin filminde olayların cereyan ettiği mekan/ev/ ya da rahim ne dersek; Khõra olarak tarif edilebilir özellikleri taşıyor görünmektedir. Bu yer Derrida'cı bir perspektiften ele alınacak olursa; duyumsanamaz, vahşet olmaksızın geçirimsiz, aktarımsı olan ve retoriğe 
aldıış etmezliği oranında cesaret kıııcıdır. "Söylemin figürlerine, kinayelerine veya baştan çıkarmalarına inanma eğilimine sahip ve inandırma arzusu duyan herkesin gayretini boşa çıkaran şeyin ta kendisidir" (Derrida, 2008, s. 8). Khõra, rahim, yatak anlamlaryyla hem anneye ait olan, hem de bakire olan olarak, sessizce ona verilen takma ismi çağırır ve kendini "anneye, kadına veya teolojiye ilişkin her türlü figürün ötesinde tutar" (Derrida,2008, s. 8). Aronofsky'nin mekanı, Khõra olarak, vaatte bulunmaksızın bir düşüncenin, daha çok siyasal olanın sınamadan geçirilmesinin haberini verir.

Filmin gizil dinamiklerinden birini, böylece ' $O$ ' ile 'Khõra' arasındaki ilişki üzerinden ele almamız da mümkün hale geliyor. Bir yatak, kalıp, rahim olarak ev, 'O' ya aittir. En başından beri 'O'nundur. Filmin daha açılış sahnelerinde eve ilişkin zamanın yıpratıcılığına da, evin sürekli yenilenmesine de tanıklık ederiz. 'O', bir yazar olarak insanlara hitap ederken, aslında tam da 'o'na Khõra'ya benzemeye, "daima fark edilmeden kalacak bir kurmaca içinde 'o' nu oynamaya, 'o'nu, dokunulmadan kalanı, kavranılamaz olanı, olası olmayanı, hem çok yakın, hem de sonsuzca uzak olanı her türlü mübadelenin ve armağanın ötesinde her şeyi alan 'o'nu göstermeye koyulur" (Derrida, 2008, s. 8).

Aronofsky'nin Anne filminin imlediği kendinde 'şey'e dair şunlar söylenebilir: 'O' Sadece oradadır. Baba-nın - Adları'ndan biri olarak, 'öteki'lerden biri olarak, başka olarak, arzu olarak, fantezi olarak, travma olarak, gerçek olarak oradadır. Sonsuz döngünün 'Yasa'sı olarak, sadece oradadır.

\section{SONUÇ}

Bu makale, Aronofsky'nin 'Anne' filmini, Lacancı psikanaliz yöntemiyle birbirine teğellemeye çalışmış olmakla birlikte, filmdeki dinsel-mitsel göstergelerin, Lacancı psikanalizin kavramlarıyla birlikte çapraz bir okumasını içermektedir. Filmde, bakışın-Lacancı imkansız bakış- işleyişine dair bir anlayış sunulmaya çalışılmıştır. Bakış, Lacan'ın "Simgesel-İmgesel-Gerçek" üçlemesinde, ilk zamanlardaki seminerlerinde, genellikle İmgesel'in alanı içerisinde ehlileştirilmiş bir tarzda ele alınıyordu. Burada, makalenin geneli içerisinde, 'bakış', gerçeğin etki alanı içerisinde ele alınmaya 


\section{$\operatorname{arts}=$}

çalışılmış olup, 'gerçekteki bakış' olarak, ifade edilemezliği içinde, filmin tamamında radikal bir potansiyeli gösteren bakış olarak ele alınmıştır.

Filmde, Lacancı 'Gerçek' ile meydana gelen travmatik yüzleşme anları, filmi de, Lacancı Psikanalizi de (Lacancı film teorisi olarak), ideolojinin yetki alanına yerleştirir. Filmin merkezinde, güç konusu kadar katmanlı bir konu olan, güçsüzlük, iktidarsızlık ve zevk (Jouissance) de ideolojik bir imleç olarak bulunur. Filmin nihayetinde, Arzunun ve fantezinin de politik bir etkiye sahip olduğu ortaya çıııor ve bu politik etkinin alanı vaat, kurban ve katıksız şiddet olarak değerlendirilebilir.

Sinemanın ideolojiyle olan ilişkisindeki temel boyut, izleyiciye; travmatik gerçekten kurtaran bir fantezi mekanı önerebilme becerisiyle anlaşılabilir. Aronofsky'nin 'Anne' filminde de bu açıdan, ideoloji ve radikal anlatı çakışır. Film boyunca travmatik gerçekle olan temas bakışın imkansızlığında gerçekleşir. Psikanalitik yorumlama, travmatik Gerçekle ve etkileriyle (burada filmde) ilgili bir tecriti, soyutlamayı gerektirir. Travmatik Gerçekle yüzleşme anı, anlamın da çöktüğü yerdir. Ancak anlamın çöktüğü nokła ile kurulan özdeşleyim yoluyla anlamı yeniden keşfedilir.

Çağdaş sinema örneklerine genel olarak baktığımızda, bugün Lacancı Psikanalizin film teorisi olarak ele alındığı birçok örneğe rastlayabiliriz. Ya da şöyle ifade edelim; Çağdaş sinema örneklerinin birçoğu, temelde bir travmatik Gerçek etrafında örülür. Buna dahil olan, arzu, güç, fantezi bakış, ideoloji gibi unsurlar, psikanalitik yorumlamanın özneyi anlama yönünde bir anahtar sunduğunu söyleyebiliriz. Bu aynı zamanda anlama ilişkin, anlamın çöküşüne ve yeniden keşfine yönelik bir görü sunar. Aronofsky'nin 'Anne' filmi, bu açıdan yaratıışa ilişkin dinselmitsel anlatıların bilinçle ve bilinç dışıyla ilişkisini, Gerçeğin travmatik etkileri dahilinde, Yasanın-Adı olarak ele alırken, psikanalitik yorumlamayı da mümkün kılmış oluyor. 


\section{KAYNAKÇA}

Blaise, P. (1654), Memorial, Grand Rapids, Ml: Christian Classics Ethereal Library

Derrida, J. (2008), Khõra, (Çev: Didem Eryar), İstanbul, Kabalcı Yayınevi.

Derrida, J. (2008), İsim Hariç, (Çev: Didem Eryar), İstanbul, Kabalcı Yayınevi,

Eisenstein, P. (2014), Lacan ve Çağdaş Sinema, (Editör: Todd McGowanSheila Kunkle, Çeviren: Yasemin Ertuğrul-Caner Turan), İstabul, Say Yayınları.

Eski Ahit, Bap 3, 13-14.

Lacan, J. (2014), Baba-nın-Adları, (Çev: Murat Erşen), İstanbul, MonoKL Yayınları.

Lacan, J. (2017), Benim Öğrettiklerim, (Çev: Murat Erşen), İstanbul, MonoKL Yayınları.

\section{Ek okumalar:}

Lacan, J. (2013), Psikanalizin Dört Temel Kavramı- Seminer 11. Kitap, (Çev: Nilüfer Erdem), İstabul, Metis Yayınları.

Zizek, S. (2008), Yamuk Bakmak, (Çev: Tuncay Birkan), İstanbul, Metis Yayınları.

Zizek, S. (2008), İdeolojinin Yüce Nesnesi, (Çev: Tuncay Birkan), İstanbul, Metis Yayınları. 